\title{
An Experimental Analysis of many Solid Chemicals in Buildings Constructions
}

\author{
Monika Soni \\ President, Auricle Global Society of Education and Research \\ India \\ 12.monika@gmail.com
}

Abstract

By and by a days, relentless endeavors made on concrete found that changing compound organizations in concrete show different features. For by and large various conditions, the sorts of concrete that could be made particularly by relative extents of the oxide organizations were not seen as sufficient. Tests have been taken to add new materials to the concrete known as added substances, at the hour of pounding or by changing principal crude materials during the creation of concrete.

Keywords: cement, grinding, chemical composition etc.

\section{INTRODUCTION}

Asia being the second greatest producer of concrete furthermore relies a ton upon the concrete business in right now. Concrete industry assumes a central job in the turn of events and improvement of Asia. It is restricting substance required while building something. The concrete business offers work to an enormous number of people in Asia, from laborers to top architects all some spot are dependent on the concrete business for their pay. Asia has a lot of capability of creating in the foundation and development portion which is valuable for the concrete business. A ton of progression to the extent creation lines, plants and housing workplaces is found in our country. As it is a making nation; ascend in populace has seen an extension in requests for occupations and trainings which subsequently has provoked a climb in the advancement of schools and associations. According to the continuous examination, there are around 188 huge plants and 365 little plants in Asia; most of them arranged in Rajasthan, Tamil Nadu and Andhra Pradesh. Concrete solicitation in Asia is required to increase with the up and coming government ventures. Asia's concrete solicitation is most likely going to show up at 600 million tons for every annum by 2025. That day isn't very far away when Asia from being the ensuing will transform into the greatest producer of concrete. Concrete is a structure material and has used on 
improvement works. There are accessible of concrete available in the market. Concrete basically available two structures are dim dry concrete and white concrete.

\section{TYPES OF CEMENT THEIR USES AND PURPOSES}

\section{Portland Cement}

It obtained by burning together in an extent of argillaceous that containing alumina and calcareous that containing calcium carbonate or lime materials to incomplete combination at high temperature 1450 degree $\mathrm{C}$. The regular calcareous material are limestone, chalk and so forth. The argillaceous material are clay, shale, slate and so on

Since, the raw material comprise principally of lime, silica, alumina and iron oxide which is significant constituent of Portland cement. It is usually utilized kind of cement creation of cement. In the structure development, concrete is utilized for the development of pillar, section, chunk, establishment and other burden bearing component

\section{Types of Portland cement}

\section{Ordinary Portland cement (OPC)}

It has great resistance from breaking and dry shrinkage yet less resistance from chemical attack. It isn't appropriate for the construction work which is presented to sulfates in the soil. There are three grade as 33,43 and 53 .

\section{Portland Pozzolana Cement (PPC)}

It very well may be created by intergrading the predetermined quantities of Portland cement clinker and pozzolana materials ( 15 - 35 percent by mass of Portland pozzolana cement) and limited quantity of gypsum. The various pozzolana cement delivers less heat of hydration and offer more prominent resistance from the sulfur attacks and chloride-particle penetration because of polluting influence in water than ordinary Portland cement. It helpfully utilized for sewer and sewage removal works. It is especially valuable marine and hydraulic driven development and elevated structure, under water concrete structure as bridge, dam etc.

\section{Rapid Hardening Portland Cement (RHC)}

It is fundamentally the same as OPC. The early quality is accomplished by including extreme $\mathrm{C} 3 \mathrm{~S}$ in the blend and by bringing down the $\mathrm{C} 2 \mathrm{~S}$ content in the cement. The quality of Fast Solidifying cement at age of 3 days is practically same as the 7 days quality of Conventional Portland cement. This sort of cement isn't utilized for massive concrete developments. It exposed to enormous shrinkage and water prerequisite for functionality is more. The expense of RHC is about $10 \%$ more than OPC. It is appropriate for repair of street and bridge. 
TABLE 1:

TYPES OF CEMENT AND ITS APPLICATION

\begin{tabular}{|c|c|c|c|}
\hline No & TYPE OF CEMENT & IS CODE & WHERE USED \\
\hline \multirow[t]{4}{*}{1} & $\begin{array}{l}\text { ORDINARY } \\
\text { CEMENT }\end{array}$ & & \\
\hline & C-33 GRADE & IS:269 & $\begin{array}{l}\text { All general Concreting } \\
\text { works }\end{array}$ \\
\hline & C-43 GRADE & IS: 8112 & $\begin{array}{l}\text { Multistorey structures. } \\
\text { Bridges or tall } \\
\text { structures. }\end{array}$ \\
\hline & C-53 GRADE & IS: 12269 & $\begin{array}{l}\text { Prestressed concrete } \\
\text { work }\end{array}$ \\
\hline 2 & $\begin{array}{l}\text { Rapid Hardening } \\
\text { Portland Cement }\end{array}$ & IS: 8041 & $\begin{array}{l}\text { Road works and } \\
\text { Repairs. }\end{array}$ \\
\hline 3 & $\begin{array}{c}\text { Low Heat Portland } \\
\text { Cement }\end{array}$ & IS: 12600 & Mass concrete Dams \\
\hline 4 & Portland slag cement & IS: 455 & Marine Structure \\
\hline 5 & $\begin{array}{c}\text { Portland Pozzolana } \\
\text { Cement }\end{array}$ & IS: 1489 & $\begin{array}{l}\text { Mass Concrete-Marine } \\
\text { Structure and general } \\
\text { building works }\end{array}$ \\
\hline 6 & $\begin{array}{c}\text { Sulphate Resisting } \\
\text { Portland } \\
\text { Cement }\end{array}$ & IS: 12330 & $\begin{array}{c}\text { Marine Structures } \\
\text { foundation in Sulphate } \\
\text { bearing soils }\end{array}$ \\
\hline 7 & Hydrophobic Cement & IS: 8043 & $\begin{array}{c}\text { Swimming pools floor } \\
\text { of food processing } \\
\text { plants }\end{array}$ \\
\hline 8 & $\begin{array}{l}\text { High Alumina } \\
\text { Cement }\end{array}$ & IS : 6452 & Marine Structures \\
\hline 9 & $\begin{array}{c}\text { Supersulphate } \\
\text { Cement }\end{array}$ & IS:6909 & $\begin{array}{c}\text { Marine Structures } \\
\text { construction of sewers }\end{array}$ \\
\hline
\end{tabular}

\section{Low Heat Cement (LHC)}

Low Heat Cement is less reactive than OPC and it is acquired by high extent of $\mathrm{C} 2 \mathrm{~S}$ and less measure of $\mathrm{C} 3 \mathrm{~S}$ and $\mathrm{C} 3 \mathrm{~A}$. This decrease in content as result moderate advancement of solidarity however extreme quality is same. It beginning setting time is more noteworthy than OPC. It is 
utilized in massive development like large footings, huge raft slabs, gravity dams \& thick pavement etc.

\section{Pozzolana Slag Cement (PSC)-}

This kind of cement made 35 to 65 percent of customary Portland cement clinker and ground granulated blast furnace slag (GBFC) ( industrial waste product consisting of mixture of lime, silica \& alumina). It has the points of interest in producing heat less rapidly than OPC . It is appropriate for mass concreting yet inadmissible cold climate as it have high sulfate resistance, it is utilized sea water development.

\section{Sulfate Resisting Cement}

It is produced by keeping the level of $\mathrm{C} 3 \mathrm{~A}$ underneath $5 \%$. This sort of cement is utilized where the structure is inclined to extreme sulfate attacks.

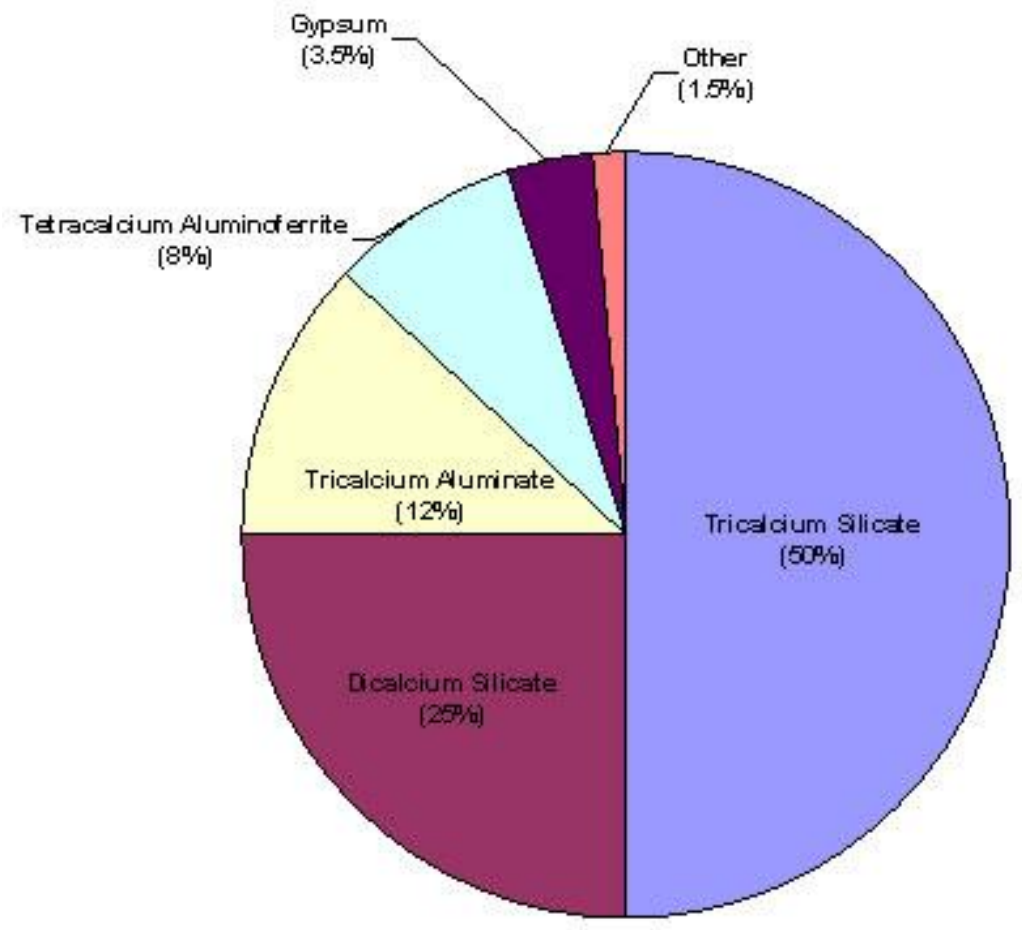

Fig 1: Portland cement composition

\section{CONCLUSION}

The above technique delivers comprehensively valuable Portland concrete that is used for most improvement purposes. It a significant structure material has accomplished a transformation in the improvement business. Its transcendence over various concretes has been a direct result of its 
strong nature, extraordinary water driven properties and the ability to pass on immense degree of aggregate. Beside this, its assembling can change over the cutting edge symptoms to crude materials.

\section{REFERENCES}

[1] E.-H. Kadri, S. Kenai, K. Ezziane, R. Siddique, and G. De Schutter, "Influence of metakaolin and silica fume on the heat of hydration and compressive strength development of mortar," Applied Clay Science, vol. 53, no. 4, pp. 704-708, 2011.

[2] V. Indrawati and A. Manaf, "Mechanical strength of trass as supplementary cementing material," Journal of Physical Science, vol. 92, no. 2, pp. 51-59, 2008.

[3] S. H. Kosmatka, B. Kerkhoff, and W. C. Panarese, Design and Control of Concrete Mixtures, Portland Cement Association,Skokie, Ill, USA, 14th edition, 2002.

[4] M. S. Mamlouk and J. P. Zaniewski, Materials for Civil andConstruction Engineers, Prentice Hall, Upper Saddle River, NJ,USA, 2006.

[5] T. Punmatharith, M. Rachakornkij, A. Imyim, and M.Wecharatana, "Co-processing of grinding sludge as alternative raw material in portland cement clinker production," Journal of Applied Sciences, vol. 10, no. 15, pp. 1525-1535, 2010.

[6] D. N. Huntzinger and T. D. Eatmon, "A life-cycle assessment of Portland cement manufacturing: comparing the traditional process with alternative technologies," Journal of Cleaner Production, vol. 17, no. 7, pp. 668-675, 2009.

[7] F. M. Lea, The Chemistry of Cement and Concrete, Arnold Publishers, London, UK, 3rd edition, 1970.

[8] J. F. Young, S.Mindess, R. J. Gray, andA. Bentur,TheScience andTechnology of Civil Engineering Materials, Prentice-Hall, Upper Saddle River, NJ, USA, 1998.

[9] H. F. W. Taylor, Cement Chemistry, Thomas Telford, London,UK, 2nd edition, 1997.

[10] S. H. Kosmatka and M. L. Wilson, Design and Control of Concrete Mixtures, Portland Cement Association, Stokie, Ill, USA, 2011.

[11] V. Sata, C. Jaturapitakkul, and K. Kiattikomol, "Influence of pozzolan from various by-product materials on mechanical properties of high-strength concrete," Construction and BuildingMaterials, vol. 21, no. 7, pp. 1589-1598, 2007.

[12] A. Neville, Neville on Concrete, ACI, Farmington Hills, Mich, USA, 2003.

[13] R. Fernandez, F. Martirena, and K. L. Scrivener, "The origin of the pozzolanic activity of calcined clay minerals: a comparison between kaolinite, illite and montmorillonite," Cement and Concrete Research, vol. 41, no. 1, pp. 113-122, 2011.

[14] K. Ganesan, K. Rajagopal, and K. Thangavel, "Evaluation of bagasse ash as supplementary cementitious material," Cement and Concrete Composites, vol. 29, no. 6, pp. 515-524, 2007.

[15] S. Sinthaworn and P. Nimityongskul, "Quick monitoring of pozzolanic reactivity of waste ashes," Waste Management, vol.29, no. 5, pp. 1526-1531, 2009. 